\title{
PERAN MEDIASI SEBAGAI SALAH SATU SOLUSI ALTERNATIF PENYELESAIAN SENGKETA
}

\author{
Faisol Rizal \\ Institut Agama Islam Bani Fattah Jombang Indonesia \\ faal rz@yahoo.co.id
}

\begin{abstract}
Abstrak: Mediasi sebagai sarana penyelesaian konflik (sengketa), tidak semata digunakan dalam ranah hukum keluarga serta hukum perdata, tetapi juga digunakan dalam lingkungan politik. Selain itu, mediasi sebagai penyelesaian konflik non litigasi juga sudah lama digunakan dalam pelbagai kasus bisnis, lingkungan hidup, perburuhan, pertanahan, perumahan, sengketa konsumen, dan sebagainya yang merupakan tuntutan masyarakat atas penyelesaian sengketa yang cepat, efektif dan efisien.
\end{abstract}

Kata Kunci: Mediasi, Penyelesaian Sengketa, Solusi Alternatif Penyelesaian Sengketa.

\section{Pendahuluan}

Perencanaan regulasi/hukum dibuat salah satunya dengan tujuan perlindungan kepada masyarakat. Pelaksanaan hukum pada faktanya berlangsung secara normal dan damai; tetapi disisi lain terkadang terdapat pelanggaran hukum. Terdapat adagium fiat justicia ruat caelum (hukum harus ditegakkan meskipun langit runtuh). Ungkapan ini mengaku pada keadilan yang senantiasa harus ditegakkan dalam kondisi apapun. Dalam perkembangan masyarakat, sering terjadi kendala dalam penegakan dan penerapan hukum. Pesatnya globalisasi menyebabkan kenaikan angka 
sengketa. Dalam hal ini diperlukan penyelesaian secara hukum dengan mempertimbangkan norma dan asas yang hidup dan tumbuh di masyarakat.

Pada faktanya, perkembangan masyarakat lebih cepat daripada perkembangan peraturan perundang-undangan. Perkembangan masyarakat tersebut menjadi titik tolak dari eksistensi peraturan. Dalam kasus tersebut, bisa dimungkinkan peraturan tidak dapat berfungsi sesuai dengan harapan karena tidak mampu mengikuti perkembangan zaman. Terdapat jarak yang siginifikan antara law in books dengan law in action. Hukum mempunyai sifat statis sedangkan aktifitas masyarakat bersifat dinamis. ${ }^{1}$

Dalam perkembangan masyarakat yang cepat, dinamis diperlukan sistem hukum dalam rangka menciptakan kehidupan masyarakat yang harmonis serta teratur. Diantara sebab ketidakmampuan hukum dalam penyelesaian sengketa adalah mengenai impotensi atau ketidak mampuan dalam penyelesaian sengketa kekinian. Permasalahan tersebut membutuhkan reposisi dalam ilmu hukum untuk dapat menemukan sebuah penyelesaian yang komprehensif, kredibel dan diterima semua pihak.

Penyelesaian sengketa dapat dilaksanakan melalui dua metode yaitu secara adjudikasi dan non adjudikasi. Dalam penyelesaian sengketa melalui proses adjudikasi, terdapat dua hal yaitu litigasi (pengadilan) dan non litigasi (arbitrase) sedangkan penyelesaian sengketa non adjudikasi atau yang disebut dengan alternatif penyelesaian sengketa (APS) dapat dilaksanakan melalui proses negosiasi, mediasi dan konsiliasi.

Di beberapa negara seperti Amerika Serikat usaha pengembangan serta metode penyelesaian sengekta melalui APS disambut baik oleh sosial sebagai upaya menghindari berperkara melalui jalur pengadilan. ${ }^{2} \mathrm{Di}$ negara lain seperti Filipina, penggunaan APS dikenal melalui penyelesaian sengketa secara kekeluargaan serta kebersamaan di tingkat pedesaan.

Dalam konteks keIndonesiaan, APS mendapat perhatian serius dengan adanya Undang-undang Nomor 30 Tahun 1999 tentang Arbitrase dan Alternatif Penyelesaian Sengketa, juga Undang-undang Nomor 2 Tahun 2004 tentang Penyelesaian Perselisihan Hubungan Industrial; yang secara subtantif, pelaksanaan penyelesaian sengketa

\footnotetext{
1 Dwi Rezki Sri Astarini, Mediasi Pengadilan Salah Satu Bentuk Penyelesaian Sengketa Berdasarkan Asas Peradilan Cepat, Sederhana, Biaya Ringan (Bandung: PT Alumni, 2013), 2. ${ }^{2}$ Rahmadi Usman, Pilihan Peneylelesaian Sengketa Di Luar Pengadilan (Bandung: Citra Adhitya Bakti, 2003), 35.
} 
sudah diterapkan secara tradisional yang dilakukan melalui peradilan adat atau peradilan desa. Penyelesaian sengketa dengan cara damai ini sudah ditgerapkan bangsa indonesia jauh sebelum kemerdekaan. Dapat diambil contoh proses penyelesaian sengketa yang diselesaikan melalui forum Runggun Adat di masyarakat Batak yang menggunakan format musyawarah dan kekeluargaan. Minangkabau juga melakukan penyelesaian sengketa melalui lembaga hakim perdamaian yang bertugas sebagai mediator atau fasilitator. Di Jawa, penyelesaian sengketa dilaksanakan melalui musyawarah oleh tokoh masyarakat atau tokoh agama.

Upaya pengenalan proses mediasi juga dilaksanakan Mahkamah Agung Republik Indonesia melalui seminar, lokakarya, rapat kerja nasional hakim seluruh indonesia serta pelatihan tentang penerapan lembaga mediasi di pengadilan. Mahkamah Agung Republik Indonesia juga mengeluarkan beberapa aturan aplikasi perdamaian dalam kasus sengketa pada pengadilan di Indonesia dengan dikeluarkannya Surat Edaran Mahkamah Agung Nomor 1 Tahun 2002 tentang Pemberdayaan Pengadilan Tingkat Pertama Menerapkan Lembaga Damai, Peraturan Mahkamah Agung RI Nomor 2 tahun 2003 tentang Prosedur Mediasi di Pengadilan yang sekarang telah dirubah dengan dikeluarkannya Peraturan Mahkamah Agung Nomor 1 Tahun 2008 tentang Prosedur Mediasi di Pengadilan sebagai penyempurnaan PERMA sebelumnya. ${ }^{3}$

Inteegrasi mediasi ke dalam format beracara di pengadilan dalam kasus perdata, diharapkan dapat menjadi salah satu instrumen dalam mengatasi permasalahan penumpukan di pengadilan; juga memperkuat dan memaksimalkan fungsi lembaga peradilan dalam fungsinya sebagai lembaga yang berwenang secara absolut mengadili dan menyelesaikan sengketa. Lembaga peradilan yang bersifat adjudikatif yang bersifat "memutus" juga sebagai lembaga acces to justice yaitu lembaga sosial kemasyarakatan yang bertugas sebagai lembaga yang memfasilitasi masyarakat dalam penanganan sengketa atau konflik.

\section{Mediasi}

Mediasi berasal dari bahasa Inggris "mediation", atau penengahan, yaitu penyelesaian sengketa yang melibatkan pihak ketiga sebagai penengah atau penyelesaian sengketa secara menengahi. Dalam banyak literatur ditemukan definisi pengertian tentang mediasi yang dikemukakan para ahli. Chirstopher W. Moore berpendapat bahwa

\footnotetext{
${ }^{3}$ Astarini, Mediasi Pengadilan Salah Satu Bentuk Penyelesaian Sengketa Berdasarkan Asas Peradilan Cepat, Sederhana, Biaya Ringan, 5.
} 
mediasi ialah intervensi dalam sebuah sengketa oleh pihak ketiga yang dapat deterima pihak yang bersengketa, bukanlah merupakan bagian dari kedua belah pihak dan bersifat netral. Pihak ketiga ini tidak mempunyai kewenangan untuk memutuskan. Dia bertugas untuk membantu pihakpihak yang bertikai agar secara sukarela mau mencapai kata sepakat yang diterima oleh masing-masing pihak dalam sebuah persengketaan. ${ }^{4}$

Dalam bukunya, Mark E. Roszkowski mengatakan sebagai berikut:

"Mediation is a relatively informal proces in wich a neutral third party, the mediator, helps to resolf a dispute.

In many respect, therefore, mediator can be considered as sructured negotiation in wich the mediator facilitates the proces"

Dalam literatur lain, sebagaimana dijelaskan pakar mengenai mediasi dengan definisi sebagai berikut:

"mediation is private, informal dispute resolution proces in which a neutral third person, the mediator, helps, disputing parties to reach an agreement.

The mediator has no power to impose a decisinon the parties".

Dengan demikian pada perinsipnya mediasi adalah cara penyelesaian sengketa di luar pengadilan melalui perundingan yang melibatkan pihak ketiga yang bersifat netral (non intervensi) dan tidak berpihak serta diterima kehadirannya oleh pihak-pihak yang bersengketa.

Pihak ketiga tersebut disebut mediator atau penengah, yang bertugas membantu pihak yang bersengketa dalam menyelesaikan masalahnya, tetapi tidak mempunyai kewenangan mengambil keputusan. Melalui mediasi diharapkan dicapai titik temu dalam menyelesaikan masalah yang dihadapi para pihak, yang selanjutnya akan dituangkan sebagai kesepakatan bersama. Pengambilan keputusan tidak berada di tangan mediator, tetapi di tangan para pihak yang bersengketa.

Raiffa melihat peran mediator sebagai sebuah garis rentang dari sisi peran yang terlemah hingga sisi peran terkuat. Sisi peran terlemah adalah apabila mediator hanya melaksanakan peran sebagai berikut:

1. Penyelenggara pertemuan.

2. Pemimpin diskusi netral.

\footnotetext{
${ }^{4}$ Bambang sutiyoso, Hukum Arbitrase Dan Alternatif Penyelesaian Sengketa (Yogyakarta: Gama Media.2008) hlm, 56.
} 
3. Pemelihara atau penjaga aturan perundingan agar proses perundingan berlangsung secara beradab.

4. Pengendali emosi para pihak.

5. Pendorong pihak/perunding yang kurang mampu atau segan mengemukakan pandangannya. ${ }^{5}$

Berdasar ketentuan Pasal 6 ayat (3) Undang Undang Nomor 30 Tahun 1999, disebutkan bahwa dalam hal sengketa atau berbeda pendapat tidak dapat diselesaikan, maka atas kesepakatan tertulis para pihak, sengketa atau beda pendapat diselesaikan melalui bantuan seorang atau lebih penasehat ahli maupun melalui seorang mediator. Kesepakatan penyelesaian sengketa atau beda pendapat secara tertulis adalah final dan mengikat bagi para pihak untuk dilaksanakan dengan i'tikad baik. Kesepakatan tertulis wajib didaftarkan di Pengadilan Negeri dalam waktu paling lama tiga puluh hari terhitung sejak penandatanganan, dan wajib dilaksanakan dalam waktu lama tiga puluh hari sejak pendaftaran.

Dalam kasus ini, mediator dapat dibedakan menjadi dua macam yaitu mediator yang ditunjuk secara bersama oleh para pihak dan mediator yang ditunjuk oleh lembaga arbitrase atau lembaga alternatif penyelesaian sengketa yang ditunjuk oleh para pihak.

Pada dasarnya penyelesaian sengketa melalui mediasi memiliki karakteristik atau unsur-unsur sebagai berikut:

1. Mediasi adalah proses penyelesaian sengketa di luar pengadilan berdasarkan perundingan.

2. Mediator terlibat dan diterima oleh para pihak yang bersengketa di dalam perundingan.

3. Mediator bertugas membantu para pihak yang bersengketa untuk mencari penyelesaian.

4. Mediator bersifat pasif dan hanya berfungsi sebagai fasilitator dan penyambung lidah dari para pihak yang bersengketa, sehingga tidak terlibat dalam menyusun dan merumuskan rancangan atau proposal kesepakatan.

5. Mediator tidak mempunyai kewenangan membuat keputusan selama perundingan berlangsung.

6. Tujuan mediasi adalah untuk mencapai atau menghasilkan kesepakatan yang dapat diterima pihak-pihak yang bersengketa guna mengakhiri sengketa.

\footnotetext{
${ }^{5}$ Suyud Margono, ADR \& Arbitrase Proses Pelembagaan Dan Aspek Hukum (Bogor:

Ghalia Indonesia.2004) hlm. 60.
} 
Seorang pakar mediasi menyebutkan bahwa mediasi tidak selalu tepat untuk diterapkan terhadap segenap sengketa atau tidak selalu diperlukan untuk menyelesaikan semua persoalan dalam sengketa tertentu. Mediasi akan berhasil atau berfungsi dengan baik jika sesuai dengan beberapa syarat sebagai berikut:

1. Para pihak mempunyai kekuatan tawar menawar yang sebanding.

2. Para pihak menaruh perhatian terhadap hubungan di masa depan.

3. Terdapat persoalan yang memungkinkan terjadinya pertukaran.

4. Terdapat urgensi atau batas waktu untuk menyelesaikan.

5. Para pihak tidak mempunyai permusuhan yang berlangsung lama dan mendalam.

6. Apabila para pihak mempunyai pendukung atau pengikut, mereka tidak memiliki pengharapan yang banyak, tetapi dapat dikendalikan.

7. Menetapkan preseden atau mempertahankan sesuatu hak tidak lebih penting dibandingkan menyelesaikan persoalan yang mendesak.

8. Jikalau para pihak dalam proses litigasi, kepentingan-kepentingan pelaku lainnya, seperti para pengacara dan penjamin tidak akan diperlakukan lebih baik dibandingkan dengan mediasi.

Erman Rajagukguk mengemukakan bahwa mediasi akan berhasil bila telah memenuhi poin sebagai berikut:

1. Para pihak ingin melanjutkan hubungan bisnis mereka.

2. Para pihak mempunyai kepentingan yang sama untuk menyelesaikan sengketa mereka dengan cepat.

3. Litigasi dianggap para pihak akan memakan waktu yang panjang, mahal dan akan menimbulkan asumsi buruk bagi kedua belah pihak karena adanya publikasi. Hal ini dapat pula ditambah persepsi tidak adanya kepastian menang perkara.

4. Meskipun para pihak dalam keadaan emosi, proses mediasi dianggap mereka sebagai tempat untuk bertemu dan menyampaikan kepentingan masing-masing.

5. Waktu merupakan poin utama dari penyelesaian.

6. Mediator yang baik akan mampu membuat kedua belah pihak berkomunikasi. Mediasi tidak akan berhasil bila salah satu pihak mengajukan gugatan atau klaim sembrono, dan pihak lainnya merasa ia akan menang melalui litigasi. Begitu juga, mediasi akan gagal bila salah satu pihak menunda-nunda penyelesaian sengketa selama mungkin, salah satu pihak atau kedua belah pihak memang beri'tikad buruk. 
Secara umum proses mediasi terbagi menjadi tiga tahapan, yaitu tahap pramediasi, tahap pelaksanaan mediasi dan tahap akhir implementasi mediasi tersebut. Ketiga tahap ini merupakan jalan yang akan ditempuh oleh mediator dan para pihak dalam menyelesaikan sengketa mereka.

1. Tahap Pramediasi

Tahapan ini adalah tahap awal dimana mediator menyusun sejumlah langkah dan persiapan sebelum mediasi benar-benar dimulai. Tahap pramediasi merupakan tahapan yang urgen, karena akan menentukan berjalan atau tidaknya proses mediasi yang akan datang. Pada tahapan ini mediator melakukan beberapa langkah antara lain: membangun kepercayaan diri, menghubungi para pihak, menggali dan memberikan informasi awal mediasi, fokus pada masa depan, mengoordinasikan pihak bertikai, mewaspadai perbedaan budaya, menentukan siapa yang hadir, menentukan tujuan pertemuan, kesepakatan waktu dan tempat, dan menciptakan rasa aman bagi kedua belah pihak untuk bertemu dan membicarakan perselisihan mereka. ${ }^{6}$

2. Tahap Pelaksanaan Mediasi

Tahap pelaksanaan mediasi adalah tahap dimana pihak yang bertikai sudah berhadapan satu sama lain, dan memulai proses mediasi. Dalam tahap ini, terdapat beberapa langkah penting antara lain; sambutan pendahuluan mediator, presentasi dan pemaparan kisah para pihak, mengurutkan dan menjernihkan permasalahan, berdiskusi dan negosiasi masalah yang disepakati, menciptakan opsi-opsi, menemukan butir kesepakatan dan merumuskan keputusan, dan penutup mediasi.

3. Tahap Akhir Implementasi Mediasi

Tahap ini dimana para pihak hanyalah menjalankan hasilhasil kesepakatan, yang telah mereka tuangkan bersama dalam suatu perjanjian tertulis. Para pihak menjalankan hasil kesepakatan berdasarkan komitmen yang telah mereka tujukan selama dalam proses mediasi. Umumnya, pelaksanaan hasil mediasi dilakukan oleh para pihak sendiri, tetapi tidak tertutup kemungkinan terdapat bantuan pihak lain untuk mewujudkan kesepakatan atau perjanjian tertulis. Keberadaan pihak lain disini hanyalah sekedar membantu menjalankan hasil kesepakatan tertulis, setelah ia mendapatkan persetujuan dari kedua belah pihak.

\footnotetext{
${ }^{6}$ Syahrizal Abbas, Mediasi Dalam Perspektif Hukum Syari'ah, Adat Dan Nasional (Jakarta: Kencana.2009) hlm, 37.
} 
Berakhirnya mediasi akan membawa konsekuensi bagi para pihak sebagai berikut:

1. Masing-masing pihak memiliki kebebasan setiap saat untuk menarik diri dari proses mediasi. Penarikan diri tersebut tidak menghilangkan beberapa konsekuensi yang timbul, misalnya keharusan untuk mengeluarkan biaya atau segala sesuatu yang telah disetujui, selama berjalannya diskusi-diskusi dalam mediasi.

2. Jika mediasi berjalan dengan sukses, para pihak menandatangani suatu dokumen yang menguraikan beberapa persyaratan penyelesaian sengketa. Kesepakatan penyelesaian tidak tertulis sangat tidak disarankan, karena hal itu akan menimbulkan perselisihan baru. Dalam praktiknya kadang-kadang sering ditemukan para pihak menolak untuk mengikatkan diri dalam suatu perjanjian tertulis, setelah mereka merasa puas dan berhasil membangun kembali hubungan baik atau mencapai kesepahaman yang memuaskan atas masalah-masalah yang mereka persengketakan.

3. Kadang-kadang jika mediasi tidak berhasil pada tahap pertama, para pihak mungkin setuju untuk menunda mediasi sementara waktu. Selanjutnya, jika mereka hendak dan ingin meneruskan atau mengaktifkan kembali mediasi, hal tersebut akan memberikan kesempatan terjadinya diskusi-diskusi baru, yang sebaiknya dilakukan pada titik mana pembicaraan sebelumnya ditunda.

Pertanyaan yang muncul selanjutnya adalah bagaimana jika mediasi tetap tidak berhasil menyelesaikan sengketa para pihak. Jika demikian halnya, para pihak secara otomatis memegang segenap hak mereka sebagaimana pada saat mereka masuk ke dalam proses mediasi. Hak-hak para pihak sama sekali tidak berkurang atau berpengaruh sedikitpun selama proses mediasi berjaalan. Demikian pula halnya, diskusi yang dilakukan selama berlangsungnya mediasi tetap bersifat rahasia. Dalam Pasal 13 ayat (1) dan (2) Perma No. 02 Tahun 2003 disebutkan "jika para pihak gagal mencapai kesepakatan, penyataan dan pengakuan para pihak dalam proses mediasi tidak dapat digunakan sebagai alat bukti dalam proses persidangan perkara yang bersangkutan atau perkara lainnya. Foto kopi dokumen atau catatan mediator wajib dimusnahkan."

Dalam kaitannya dengan kegagalan mediasi, maka proses penyelesaian sengketa dapat pula dilanjutkan melalui jalur arbitrase atau pengadilan. Pemilihan lembaga arbitrase sebagai lembaga penyelesaian sengketa memerlukan komitmen kedua belah pihak, dimana masingmasing pihak setuju dan sepakat menyelesaikan sengketa mereka melalui proses arbitrase. Dalam konteks ke-Indonesiaan, arbitrase bukanlah hal 
yang baru dan telah lama dikenal. Salah satu ketentuan yang dianggap merupakan sumber pokok dapat dilaksanakannya arbitrase sebelum berlakunya Undang-Undang No. 30 tahun 1999 adalah ketentuan yang diatur dalam pasal 337 Reglemen Indonesia yang diperbaharui. ${ }^{7}$ Jika salah satu pihak tidak menghendaki penyelesaian melalui jalur arbitrase maka dapat ditempuh jalur lain, yaitu pengadilan. Pemilihan terhadap pengadilan sebagai tempat penyelesaian sengketa tidak memerlukan kesepakatan bersama para pihak. Seyogyanya jika mereka bersepakat untuk mengakhiri sengketa melalui jalur pengadilan, karena adanya kesepakatan itu, memberikan sinyal bahwa upaya damai masih memungkinkan untuk dilakukan oleh hakim dalam proses persidangan. Akan tetapi sebaliknya, penyelesaian sengketa melalui jalur pengadilan juga dapat ditempuh oleh salah satu pihak yang bersengketa, dan tidak memerlukan persetujuan pihak lain atau komitmen bersama para pihak. Para pihak mempunyai kebebasan untuk mengajukan perkara yang mereka perselisihkan kepada pengadilan, dan pengadilan akan memproses sengketa mereka sesuai dengan ketentuan hukum acaranya.

Di Indonesia, kegagalan mediasi dan kemungkinan melanjutkan proses penyelesaian sengketa melalui jalur arbitrase atau pengadilan dapat dilihat dari dua ketentuan hukum yang berbeda. Dalam Pasal 6 Ayat (9) UU No. 30 Tahun 1999 tentang Arbitrase dan Alternatif Penyelesaian Sengketa disebutkan bahwa, jika upaya mediasi tidak dapat dicapai, para pihak berdasarkan kesepakatan tertulis dapat mengajukan upaya penyelesaian melalui lembaga arbitrase atau arbitrase ad hoc. Sedangkan dalam Pasal 12 Ayat (1) Perma No. 02 Tahun 2003, disebutkan bahwa jika dalam waktu yang ditetapkan dalam mediasi tidak menghasilkan kesepakatan, mediator wajib menyatakan secara tertulis bahwa proses mediasi telah gagal dan memberitahukan kegagalan tersebut pada hakim.

Mediasi dapat dilakukan melalui jalur pengadilan atau di luar jalur pengadilan. Ketentuan dalam UU No. 03 Tahun 1999 ditunjukkan untuk penyelesaian sengketa di luar jalur pengadilan, sedangkan Perma No. 02 Tahun 2003 diterbitkan untuk prosedur mediasi di pengadilan. Mediasi di pengadilan merupakan suatu rangkaian dengan pemeriksaan perkara di pengadilan. Bila para pihak gagal menempuh mediasi, maka hakim akan melanjutkan pemeriksaan perkara sesuai dengan ketentuan hukum acara yang berlaku.

A. Konflik

\footnotetext{
${ }^{7}$ Gunawan Widjaja dan Ahmad Yani, Hukum Arbitrasi (Jakarta: Raja Grafindo Persada.2001) hlm. 41.
} 
Istilah konflik berasal dari kata latin Conflegere yang berarti "saling memukul atau berbenturan". Dua batang kayu yang saling dibenturkan secara terus menerus sering kali bisa menghasilkan api.

Api yang diciptakan oleh konflik tidaklah harus bersifat destruktif. Terkadang para juru damai dengan penuh ketulusan hati sengaja berupaya menciptakan konflik. Konflik-konflik yang diciptakan di kawasan selatan Amerika Serikat dalam dasawarsa 1960-an melalui pemboikotan bus tanpa kekerasan menghasilkan pencabutan aneka hukum diskriminasi yang sangat tidak adil. Konflik-konflik yang tercipta lewat perjuangan aktif tanpa kekerasan yang dilakukan oleh Mahatma Gandhi akhirnya berhasil membebaskan India dari cengkraman kekuasaan kolonial Inggris. Konflik-konflik yang dipicu oleh gerakan anti-apartheid di Afrika Selatan akhirnya melahirkan perubahan konstruktif dalam sistem pemerintahan bangsa itu. Perbedaaan pokok antara konflik itu dicoba diselesaikan, khususnya apakah pihak-pihak yang terlibat dalam konflik memiliki keterampilan - dan kemauan - untuk memanfaatkan konflik ke arah terjadinya perubahanyang sungguhsungguh konstruktif. ${ }^{8}$

Media masa dipenuhi dengan berita tentang contoh-contoh konflik yang destruktif, mulai dari peperangan antar bangsa sampai pertikaian antar kelompok masyarakat dan antar pribadi. Mayoritas orang mengalami sejenis konflik tertentu setiap hari baik di dalam keluarga atau hal lainnya. Biasanya konflik tersebut terjadi apabila dua atau lebih orang merasa bahwa mereka memiliki aneka perbedaan yang mustahil didamaikan atau bila aneka sumber, relasi, kebutuhan, atau nilai hidup mereka terancam. Orang akan saling bertikai bila gagal mengatasi perbedaan tersebut dan saling menanggapi dengan cara destruktif.

1. Metode menghadapi konflik

Terdapat banyak ragam metode menghadapi konflik. Ada yang memilih diam; ada yang memilih melawan secara terbuka; dan ada pula yang memilih bernegosiasi. Seseorang dapat menanggapi konflik dengan cara yang berbeda tergantung jenis konfliknya. Cara-cara menanggapi konflik, semacam ini tidak hanya ditentukan oleh sifat konflik yang sedang dihadapi, tetapi juga oleh sejarah pribadi yang membentuk aneka sikap dan keyakinan orang mengenai

\footnotetext{
${ }^{8}$ Ronald S. Kraybill dkk, Panduan Mediator Terampil Membangun Perdamaian, judul asli Peace Skills, A Manual For Community Mediators (Yogyakarta: Kanisius.2002) hlm. 36.
} 
konflik. Beberapa faktor yang mempengaruhi sikap dan keyakinan orang tentang konflik meliputi:

- Relasi dengan kakak-adik kandung dan teman-teman bermain di masa kanak-kanak.

- Contoh cara menanggapi konflik yang ditiru dari orang tua, guru-guru dan berbagai tokoh publik.

- Aneka citra dan sikap yang ditayangkan oleh media publik, khususnya televisi, film dan internet.

- Aneka faktor sosial seperti kelangkaan berbagai sumber daya yang serius dan kemiskinan.

Langkah pertama dan terpenting ke arah kemampuan mengangani konflik dengan baik adalah mencermati aneka reaksi kita sendiri yang bersifat spontan dan sering kali tidak kita sadari terhadap konflik, serta akibat-akibat dari reaksi kita itu terhadap orang lain.

2. Sumber dan jenis konflik

Terdapat banyak cara untuk menganalisis konflik serta mengidentifikasikan anaka faktor yang "menyebabkan" atau menyumbang bagi terjadinya konflik tersebut. Sekalipun mungkin terdapat hanya satu kejadian pencetus yang mengantarkan pihak-pihak yang bertikai dalam konfrontasi, namun kebanyakan konflik, khususnya konflik-konflik yang berlangsung di tengah-tengah masyarakat, timbul dari serangkaian faktor yang kompleks dan menyangkut orangorang yang terlibat di dalamnya: kesamaan sejarah yang dimiliki; dinamika lingkungan sosial, politik, atau ekonomi; dan tentu saja, persoalan-persoalan tertentu yang menjadi pangkal silang pendapat di antara orang-orang tersebut. Sebagai contoh, di salah satu kelompok masyarakat, konflik yang terjadi di lingkungan dewan sekolah setempat berkisar seputar rencana pengambilan suara untuk pengadaan sejumlah ditektor logam untuk sebuah Sekolah Menengah Atas dengan menggunakan dana yang semula dicadangkan untuk keperluan perbaikan sistem persekolahan. Walaupun demikian, sang mediator melihat bahwa banyak faktor lain perlu dipertimbangkan untuk memecahkan konflik ini secara konstruktif - rasa takut yang diungkapkan oleh para guru menyangkut keamanan di lingkungan sekolah, keadaan ekonomi para warga masyarakat yang tidak terlalu stabil, kecurigaan antar-ras di kalangan dewan sekolah dan di tengah masyarakat, persaingan kekuasaan di kalangan 
anggota dewan sekolah dan warga masyarakat, dan sebagainya.

Sering kali bermanfaat untuk mendekati konflik dengan cara mengkaji persoalan-persoalan yang dipersengketakan. Konflik biasanya muncul dari salah satu atau beberapa persoalan berikut ini:

- Informasi.

- Sunber daya.

- Relasi.

- Kepentingan atau kebutuhan.

- Struktur (kemasyarakatan atau keorganisasian).

- Nilai-nilai hidup.

a. Konflik menyangkut sumber daya

Konflik menyangkut berbagai sumber daya materi seperti tanah, uang, atau benda-benda lain biasanya mudah diidentifikasi dan sering kali mudah diselesaikan melalui jalur tawar-menawar. Namun, terkadang kendati di permukaan pihak-pihak tersebut seperti salling mempertikaikan sumber daya tertentu, tetapi sesungguhnya konflik itu menyangkut suatu perkara lain, mungkin tentang relasi atau kebutuhan psikologis salah satu atau kedua belah pihak.

b. Konflik tentang relasi

Dalam hubungan keluarga, kemitraan bisnis, atau organisasi kemasyarakatan orang sering bersilang pendapat tentang berbagai perkara, namun terkadang saling ketergantungan yang tercipta oleh relasi mereka itu melahirkan demensi destuktif pada aneka perbedaan yang terjadi di antara mereka yang semestinya mudah diselesaikan. Aneka kejadian di masa lalu atau kesan prasangka tertentu yang sudah terbentuk selama bertahun-tahun bisa membuat orang sangat kaku atgau tidak mau mencoba menempuh solusi yang amat sangat jelas dan gamblang. Kejelasan tentang tujuan, peran, tanggung jawab, dan perbedaan pandangan tentang pengalaman masa lalu perlu diselesaikan sebelum konflik-konflik yang lain dapat dipecahkan.

c. Konflik menyangkut kepentingan atau kebutuhan

Aneka kebutuhan manusiawi yang penting dan kuat seperti kebutuhan akan jati diri, harga diri, atau partisipasi sering kalli menjadi inti konflik yang di permukaan terkesan seperti persaingan menyangkut benda-benda materi semata. Kesempatan yang konstruktif bagi individu atau kelompok masyarakat untuk mengungkapkan aneka kebutuhan mereka dan merasakan bahwa diri mereka telah didengarkan sering kali amat menentukan dalam mengatasi jenis-jenis kebutuhan ini. Pemecahan jangka panjang terhadap suatu konflik yang berkisar pada sumber daya 
sering kali ditentukan baik oleh pemuasan aneka kepentingan atau kebutuhan orang-orang yang terlibat maupun oleh pembagian aneka sumber daya tersebut secara adil.

d. Konflik menyangkut struktur

Struktu kemasyarakatan dan organisasi menentukan siapa yang memiliki akses pada kekuasaan atau sumber daya, siapa yang wajib memberi hormat kepada siapa, dan siapa yang memiliki wewenang untuk membuat aneka keputusan. Konflik menyangkut atau di dalam struktur sering kali melibatkan persoalan tentang keadilan dan tujuan-tujuan yang saling tidak sejalan. Konflik-konflik semacam itu sering kali menuntut usaha bertahun-tahun untuk menghasilkan perubahan yang konstruktif.

e. Konflik menyangkut nilai hidup

Berbagai nilai hidup dan keyakinan dibentuk oleh pengalaman hidup dan iman kepercayaan. Karana ancaman terhadap nilai-nilai hidup seseorang sering kali dipandang sebagai ancaman terhadap jati dirinya, maka konflik-konflik menyangkut nilai-nilai hidup biasanya paling sulit dipecahkan. Kebanyakan orang bereaksi secara defensif terhadap ancaman semacam ini. Dan menolak untuk bernegosiasi, mengira bahwa pemecahan konflik tersebut menuntut mereka untuk mengubah nilainilai hidup. Dalam kenyataan, dengan memberi kesempatan kepada orang yang bertikai untuk menjernihkan nilai-nilai hidup mereka dan merasa bahwa mereka telah didengarkan serta dipahami sering kali langkah itu dapat membuat mereka meninggalkan sikap defensif dan belajar hidup bersama dengan saling menerima berbagai perbedaan yang ada di antara mereka.

Mencoba memahami suatu konflik dengan mempertimbangkan orang-orang yang terlibat, sejarahnya, lingkungan sosialnya, persoalanpersoalan yang terkait, dan berbagai faktor yang menyebabkan atau setidaknya memberikan kontribusi bagi munculnya konflik tersebut bisa memerdekakan baik sang juru damai sendiri maupun pihak-pihak yang bertikai. Proses semacam ini dapan menolong menguraikan sebuah konflik yang kompleks ke dalam bagian-bagian yang lebih mudah ditangani serta membuka jalan bagi aneka pendekatan ke arah pemecahannya.

\section{Kesimpulan}

Mediasi merupakan salah satu alternatif penyelesaian sengketa non adjudikatif yang menjadi salah satu alternatif penyelesaian sengketa yang populer di masyarakat dalam peranannya salah satunya mengurangi penumpukan perkara di pengadilan. Sebagai salah satu metode alternatif, keilmuan mediasi bercirikan khas pembeda antara mediasi dengan 
metode alternatif penyelesaian sengketa yang lain dalam keilmuannya secara teoritis maupun praktis.

\section{Daftar Pustaka}

Sutiyoso, Bambang. 2008. Hukum Arbitrase Dan Alternatif Penyelesaian Sengketa. Yogyakarta: Gama Media.

Margono, Suyud. 2004. ADR \& Arbitrase Proses Pelembagaan Dan Aspek Hukum. Bogor: Ghalia Indonesia.

Abbas, Syahrizal. 2009. Mediasi Dalam Perspektif Hukum Syariah, Adat Dan Nasional. Jakarta: Kencana.

Widjaja, Gunawan dan Ahmad Yani. 2001. Hukum Arbitrasi. Jakarta: Raja Grafindo Persada.

Kraybill, Ronald S. dkk, 2002. Panduan Mediator Terampil Membangun Perdamaian, judul asli Peace Skills, A Manual For Community Mediators. Yogyakarta: Kanisius. 